\title{
The United States' China Containment Strategy and the South China Sea Dispute
}

\author{
Victor Teixeira
}

The common contention regarding the South China Sea is that its characteristic assets are the central or even the sole explanation for the debate. However, it is the argument of this study that this view is distorted and perilously deceptive. This study argues that there are multiple explanations for these territorial disputes and that they are significantly complicated by the proximity of a few players, the ascent of powerful new forces, the impact of financial power, the dispersion of military and political power, and geopolitical rivalry in Asia. The Unites States views China as a threat to its global hegemony and so has a policy of 'containment'. In the context of the South China Sea, its policies therefore are not intended to resolve disputes in a mutually beneficial way, but to limit China's influence. This forces countries to 'choose sides' rather than engage in mutually beneficial trade. The policy has now also led to a trade war, which could escalate into a military confrontation. This investigation examines the progression of this debate by taking into consideration the various geostrategic, geo-economics, and geopolitical interests of the parties involved and suggests a fundamental paradigm shift in the direction of research to be more conducive toward finding a realistic and peaceful resolution to the disputes in the South China Sea.

Keywords: economic containment policy, US-China relations, geostrategies, geo-economics, South China Sea.

Victor Teixeira. The United States' China Containment Strategy and the South China Sea Dispute. Central European Journal of International and Security Studies I3, no. 3: I66-I93.

(C) 2019 CEJISS. Article is distributed under Open Access licence: Attribution NonCommercial 3.0 Unported (cc by-nc 3.0). 
The purpose of this article is to establish the geopolitical issues surrounding the South China Sea (SCS) in the past decade. Among other issues, the study will identify the vested interests of the West, the United States and the European allies, as far as the South China Sea is concerned. On the greater scale, the article will unearth the emerging significance of the United States' pivot to Asia, besides offering detailed research on the reasons and dynamics for this abrupt change by world's most powerful country. It will help the reader, or people with interests in global politics to understand the specific subject matter surrounding the SCS. Further, taking the SCS as a case study, the reader will be able to make relative generalizations of the arguments to other similar disputes featuring geopolitical interests. To authenticate the argument, the article borrows knowledge through a literature review of the realists' and the idealists' view on the matter. The two groups present a somewhat similar view to the argument of the paper. For instance, China was labelled the "sleeping giant" by Napoleon who dared not wake it up until it was woken up later by the invasion of Japan, the civil wars, the imperialism and monarchy. However, ever since the death of Mao in I976, the 'giant' seems to have woken up from its sleep and it truly is shaking the world with the present challenge to the U.S. security. Considering the fact the U.S. had enjoyed unrivalled world superpower for decades, the big question is how then can they contain China without a possibility of war breaking out? Liberalists advocate a policy of economic and institutional inclusion to integrate China in the global economy. Their point of view is that if China can rise peacefully, the possibility of a war breakup will be minimal. Realists, on the other hand, call for an aggressive approach to China's growth, featuring aspects like containment policy. Their view is that China's growth is a threat to America's hegemony and that it should be controlled to avoid a challenge to the status quo. This article is of the view that the adoption of democratic channels and withdrawal of military interventions would be crucial to realization of peace and stability around the SCS as well as between China and the U.S. The abandonment of the containment policy and a paradigm shift by the U.S. to view China not as an enemy but as a partner can lead to resolutions in the territorial disputes in the SCS.

\section{Introduction}

The South China Sea is a marginal sea making part of the greater Pacific Ocean, with an approximate area of 3,500,000 square kilometers 
(I,400,000 sq. mi). Despite its comparatively smaller geographical area, the interest it draws form the world's superpowers is significant for various reasons. First, the sea is strategically positioned with reference to the major trading routes across the world as shown by the

CEJISS fact that one-third of the worlds' shipping have to pass through the 3/20I9 region to and from their destinations. The numerous international transactions that take place within the region yield approximately U.S. \$3 trillion in a year, a partial explanation for the increased interest by the international community in the region. Furthermore, the region harbors huge untapped oil and gas reserves in its seabed. The strategic positioning of the region and the natural resource endowment therefore explain the recent increased interest in this region of the Pacific sea.

Coupled with the two leading reasons highlighted above, the unsaid truth about the conflicts surrounding the South China Sea, however, is the ascension of China in the pecking orders of the world to make its statement as a great power as marked by the significant developments in various of its economic sectors comparative to the contemporary global system. Indeed, according to Regilme, it is the rise of China that ultimately can be credited with creating the conflict in the South China Sea. Domestically, the efforts of Chinese President Xi Jinping to increase China's stature in the world, and his control domestically, necessarily means challenging the US, especially in Southeast Asia, China's backyard. ${ }^{1}$ However, China's increasingly aggressive moves in the region have forced many Southeast Asia countries preferentially turn towards the US, as a means of protecting themselves from being overwhelmed by China.

For the last three decades, China has made remarkable improvements in modernizing its military. The progress has come despite the notably lower budgetary allocation by the China government to the course, as revealed in the country's transparency policy, as compared to the United States' hefty military funding with no revelations. Besides the resurgence of China, the country has increasingly been involved in diplomatic interventions aimed at achieving peace in regions that were recently involved in skirmishes. The involvement of China in international matters in regions such as Africa, Latin America and Southeast Asia denotes the political maturity that the country has achieved over the years. This is translated as a shift in power balances by the U.S. and her allies in the Asia Pacific region. ${ }^{2}$ 
The traditional powers, including the U.S. and several European nations, feel threatened by the rise of the Asian economy, led by China. As a result, the former countries have their antennae on alert to combat any further rise which might see the status quo challenged, or a shift in power and world control take place. With limited legitimate alternatives left, the U.S. and its allies are left with few options on how to put checks on China and Asia at large to reduce the potential threat that they pose internationally. Desperation has left the aggressors with the alternative of curbing the growth of the economies of the target regions and countries through unfair economic sanctions and bans. A classic example of the same is the U.S. containment policy which is discussed at a later stage of this study. Critics have labelled such moves by U.S. and its allies as unnecessary and detrimental to the target countries and regions. Further, the moves seem to go against the democracy which the U.S. government seems to always profess, besides infringing on the sovereign rights of the people and the governments of the affected regions. In cases where the economic sanctions and containment policies are not applicable, civil war becomes the other option.3 With civil wars, a region or a country would have its long terms goals thwarted and derailed as well. Geopolitical interests can be used to explain many of the civil wars around the world, including the South China Sea area, which has had a fair share of its own. For instance, the dispute in SCS resonates from "vital" issues such as territorial sovereignty, economic development, military security and political legitimacy for China and other claimants. Civil wars will see any development projects within a region halted, either through a court process or through armed forces. Such acts come with heavy losses in finances and capital resulting from the idle capacity. In some other instances, the regions may lack peace and as a result, the normal human life and businesses will not take place. Any time that passes by represents a loss in GDP.4 Such is the predicament of the South China Sea. The containment policies attached to the regions are strategic tools used by U.S. and its allies to see to it that neither China, nor the greater Asia continent benefits from the strategic positioning of the SCS.

\section{The US containment strategy}

Different authors have discussed the issue of the United States' actual intentions in its involvement in South China Sea. Some authors argue that US intentions are clear and honest and are aimed at bringing
The US Strategy

for China

Containment 
peace in the region while some authors argue that United States has some hidden intentions which can cause major setbacks in attempts to keep peace in the region. According to Glaser, ${ }^{5}$ the United States' participation in South China Sea is based on its struggles to maintain har-

CEJISS mony in the area by enhancing sovereignty in navigation around the 3/20I9 South China Sea, facilitating passage of trade items around the area without restrictions and also resolving problems peacefully between different parties around the area. Glaser ${ }^{6}$ makes it clear that US intentions are all aimed at maintaining peace in the region and enabling all parties involved to benefit. He explains that failure to carry out these roles would undermine the United States position as a leading nation in the world and this is the main reason why US has sacrificed many resources on the South China Sea dispute.

According to John Mearsheimer, ${ }^{7}$ the attempt by China to climb the ladder in terms of economic class and challenge the United States will be a violent venture. Mearsheimer says that China has set its efforts in gaining control over the area of Pacific- Asia while the United States is interested in taking over the western region. The need for these two regions to dominate areas around them is to attain a position of being superior over their surrounding countries therefore gaining a sense of security that there will be no challengers arising from these neighboring nations. The United States is feeling threatened by the steady growth of China as a superpower, therefore it has developed a strategy that is aimed at slowing the growth. ${ }^{8}$ The U.S has come up with a policy known as containment policy that will ensure that the expansion of China is curtailed therefore its probability of becoming a super power is reduced. In regard to the containment policy, America is trying to get into diplomatic agreements with nations surrounding China therefore shifting their support to it. ${ }^{9}$ It's important to note that the US has increased its contact with states such as Vietnam and India and is increasingly entering into agreements with the two countries. These actions by the United States are not aimed at improving its internal relations with these countries but they are aimed at weakening the support of China from its surrounding countries to ensure that it does not enter the political and the economic realm.

On the other hand, China is feeling the pressure of the policy being used by America to contain its growth and has in turn reapplied similar strategic pressures to its bordering countries. ${ }^{1011}$ According to John Mearsheimer, Australia should be on the lookout for the competition 
and the aggression between the two great nations because their conflict would see the stability of the area affected.

Conforming to John Ikenberry, ${ }^{12}$ China is growing at such a fast rate in that it is posing a risk to the US's global hegemony. The use of containment policy to ensure that China does not speedily grow is damaging to the economies of the sphere with the economy of the US not being spared. In that case, the United States should approach the problem of China through a strategy that limits the creation of curtailing alliances with China's neighboring countries to such an effect that the growth of China is supported by liberalism instead of negative brute effects of hegemonic imperialism ${ }^{13}$ For instance, economic liberalism can allow for a free-trade unilateral agreements between China and other countries of the world. Moreover, it is within the culture of liberalism that China must offer a platform of fully-opening its markets as has done Washington. Such a liberal form of interests can allow the United States to moderate the amount of economic pressure it is putting on China so as to allow it to be the sole provider of economic security within the whole of East Asia. Nevertheless, it is critical to note that despite the current economic tensions between the two countries, China has already taken US's offer by allowing for a slow yet systematic opening of its economic borders and improving its international institutions especially with regard to its economic niche in East Asia. ${ }^{14}$

This approach by America is a safe one and will decrease the agitation between China and its adjustment countries as it will be allowed to engage with them through trade and other diplomatic issues thus it will grow. However, this growth will be toned down at the point where it is restricted from engaging in the security matters of the western and the pacific-Asia region. ${ }^{15}$

In consonance with Joseph Nye, America ought to use both the strategies of realism and liberalism while dealing with the growth of China to become the global leading economy commonly known as Smart Power. Smart Power is the capacity to use hard and soft power interchangeably to ensure that the intended results are attained. In this case soft power is the liberalism strategy whereby America enters into a pact with China allowing it to grow without constraints and it takes the docket of securing the Western and Asia-Pacific region, while hard power is the realism strategy whereby the containment policy is brought into use. ${ }^{16}$ The use of realism strategy by the US seeks to pro- 
tect its concerns and position in the world. In this case the political scientist claims that America is justified to use its containment policy against growth and challenging it in the political and economic ream. It is important to note that having a little control and engagement with CEJISS the countries surrounding China will deter it from growing progres3/20I9 sively in that the policy works just fine and America will retain its position in the world. In addition to use of the realism strategy, America uses its diplomatic tactics to engage China and enter into a pact with it to ensure that the rivalry between them is neutralized. ${ }^{17}$

The United States is applying the art of liberalism which allows China to trade and enter into agreements with other countries but on the terms that it provides security to East Asia countries. The use of the two strategies works for the two countries as China is forging forward towards its attainment of its position in the global sphere while the United States is working to retain its position by restricting China's rise without triggering any attack by China despite implementing its containment strategy. ${ }^{18}$

Research has also been carried out on ways in which United States can win over China in their contention on South China Sea. Indeed, one element of the efforts has focused on supporting the 2016 decision in the dispute between China and the Philippines by the Permanent Court of Arbitration (PCA) in The Hague. According to the decision, China did not have a legal basis its territorial claims vis-à-vis the Philippines. While the US points out the effect of the ruling in the SCS and beyond, the question as to whether China will be influenced by the same is a matter of time. Critics of the International Tribunal for the Law of the Sea or the International Court of Justice, as it is famously referred to, once applauded the court for giving a sweeping victory to the 'underdog' in the legal battle, the Philippines. The legal institution for the first-time did not adjudicate on the matter of sovereignty but rather on the weight of the content contained therein, with the court. China's is under reservations after the ratification of the United Nations Convention on the Law of the Sea (UNCLOS), which prohibits the politically 'bigger' countries against compulsory dispute settlement under the Convention, a move which makes the ruling legally binding and enforceable in the context of China. The panel established that China claimed no historic rights in the nine-dash line, which is used by Beijing to demarcate its interest in the South China Sea, to be legally baseless. 
According to latest developments, China-US relations are about to collapse especially due to various remarks that have been made by both parties. In 20I7, the new elected US secretary of state's announced that China should stop building in their artificial island along South China Sea and they should not access the islands too. In response, Beijing responded by making it clear to United States that unless US launches war on China, the construction cannot be stopped. ${ }^{19}$ These two remarks are a clear signal that the two countries are ready for war unless intervention is carried out. Authors have responded by coming up with different ideas on how the problem can be stopped before it is too late.

Recently the world has witnessed the creation of $\mathrm{Xi}$ Jinping's personal political ideology, which will entrench his position in the legacy of the Communist Party on a footing equal to that of Mao Zedong or Deng Xiaoping. Xi's 'theory' emphasizes China's nascent ascension to the status of a great power, as can be evidenced through such statements by Xi himself as 'It is time for us to take center stage in the world and to make a greater contribution to humankind'. ${ }^{20}$ This shows a leader with confidence asserting that his country has already become a great power; while also reinforcing China's political culture. For Xi Jinping, China's socialist democracy is the world's most genuine and most effective democracy to safeguard his people; China doesn't need to copy any other political system. Regarding the South China Sea, Xi Jinping noted that the artificial islands were a significant development of the last five years, heightening tensions with other stakeholders (including the United States). ${ }^{21}$ The President also noted that China is not seeking conflict, but nonetheless highlighted the reorganization of China's military as a significant achievement over the last five years and further promised continued changes including increasing the professionalism of officers and improvements in weaponry, promising that China's military capabilities would be first class in all fields.

A few hours later, the United States Secretary of State, Rex Tillerson said 'America would deepen cooperation with India in the face of a growing Chinese peril in Asia'. According to Tillerson's speech as given at the Center for Strategic and International Studies, China is a non-democratic society and America should recognize India as a potential partner in a strategic economic and political relationship that could never happen with China. ${ }^{22}$ In Tillerson's words, China has sometimes acted outside of accepted international norms, and he gave the South China Sea Dispute as an example. In Tillerson's words: 'We
The US Strategy for China Containment 
will not shrink from China's challenges to the rules-based order and where China subverts the sovereignty of neighboring countries and disadvantages the US and friends. ${ }^{23}$

Taken together, it would seem that Asia has become a priority in CEJISS American foreign policy, politics, and ideology. ${ }^{24}$ Asia is transcending 3/20I9 the present dimensions of geopolitical power and restructuring the dynamic of geopolitics towards one that focuses on economic efficiency rather than military might. America's concern with the South China Sea is not merely due to any fear of a potential military escalation in the region or even commitment to treaty allies; rather, America's involvement in the dispute is an attempt to contain an ascendant China. In other words, China's nascent ascension to the status of a regional and global power represents the antithesis of the established global order which threatens America's own hegemony. Containing China is a platform held up by two pillars, one geopolitical and one geostrategic. Geopolitically, containing China reduces her to the status of a regional power. Geo-strategically, containing China ensures the continuing dominance of the American hegemony. This view is supported by Peter Navarro ${ }^{25}$ who observes, 'The United States does not tolerate peer competitors. As it demonstrated in the twentieth century, it is determined to remain the world's only regional hegemony. Therefore, the United States can be expected to go to great length to contain China'.

According to Navarro and Peter, America's major concerns in Asia is not finding a resolution to the South China Sea conflict, but balancing Chinese growing influence. The US policymakers' obsession with China's growing popularity is ill-advised and bound to bring more harm than good. The question is, does the containment strategy mitigate issues in the SCS?

The theory of containment was imposed by the US to prevent the spread of Soviet idealism after the Second World War. This theory speculated that any country that adopted Soviet influence could subsequently influence all neighboring countries through a domino effect. ${ }^{26}$ In other words, the US government has become used to considering the world, especially after the Cold War, as if it were a chessboard, albeit a board on which it is the only player in the game and the others are pieces. ${ }^{27}$

Since its foundation, the US has consistently oriented its strategy toward the acquisition and maintenance of its predominant power over 
its rivals, first in the North America, then in the European hemisphere and, finally, globally. This strategy was called containment during the Cold War. ${ }^{28}$ This policy of containment is composed of several dynamics that involve treaties of mutual security, limiting access to natural resources and preserving the military, economic and technological supremacy of the US.

The US created an international system designed for its interests and to maximize its national power. These dynamics are based upon three dimensions: political, diplomatic and military. The US Military is working to contain China in Asia even though political leaders of the country continue to deny it. American policymakers have developed a strategy that would check the Chinese surging military and economic power. US military forces could threaten China's trade through the South China Sea. ${ }^{29}$ The raw materials and oil transported through the sea lane in South China Sea are crucial to the rising Chinese economy.

China is believed to be designing an alternative international system to weaken the existing standard system, as highlighted by Blackwell and Tellis: $:^{30}$ 'a variety of similar bodies that privilege China's position and Undermine standards of governance set by the Organization for Economic Cooperation and Development (OECD), the World Bank, and other international institutions. ${ }^{31}$ What analysts do not see or do not want to see, because they have been moulded by the assumption that the US is the sole superpower (i.e., American exceptionalism), is that the institutions created by China and their initiatives will not undermine the international system and will constitute alternatives not only to China but also to other powers. ${ }^{32}$

Contrary to the assertions by policymakers inside the Pentagon that the US is only concerned about the escalating territorial conflicts in the SCS, Ikenberry ${ }^{33}$ noted that the strategy of the US is to enhance its military presence with military and naval training, diplomatically supporting any discretion of neighboring and allied countries in the United Nations, financially supporting these states, sharing new technologies and trying new trade agreements.

Over the last twenty years, the China and USA diplomatic relations have significantly improved save for a few mishaps that tended to derail the Sino-US relations projection. The last five administrations have tried to maintain a neutral position to the South China Sea dispute by choosing neutral language to avoid being entangled in the border dispute. The speeches by senior US administration officials often carry 
a disclaimer that the USA seeks to choose no sides in the SCS border dispute and wishes to resolve the border disputes in the SCS to be reached without coercion. ${ }^{34}$ This effort is difficult to maintain since the USA seems to be drawing many countries in the SCS border dispute to CEJISS its political-military sphere except China.

3/2019 With its vast resources and reach globally, the US Navy has the ability to represent its face fully in the Pacific region. However, when it comes to China the US Navy has been unable to engage its emerging naval power $^{35}$. The US Navy fleets in the Pacific region conduct over 700 port calls for scheduled maintenance, crew liberty, and engagements thereafter. The USA flag on the naval warships is a powerful symbol and a sign of the strength of the USA relationship with the countries they make those port calls in, a tool they have employed in the past century successfully. Since 1993 to 20II, the US Navy has however made fourteen (I4) port calls to China, which is relatively low compared to over I3,000 in the surrounding countries in the SCS in the same span, portraying the political difficulty in permission obtaining such visits in the country. ${ }^{36}$ It also portrays the inability or reluctance of the USA to make relationships with China as it has been successfully able to do with other countries in the SCS border dispute.

Is this strategic three-dimensional dynamic of the US sufficient to contain the relations between the states mentioned above and China? Does it offer any help towards regional territorial peace in the SCS?

According to Ikenberry, ${ }^{37}$ this strategy is not sufficient, and containing China is useless. China is already a world and regional power as many studies have indicated. The US response follows the military dynamics, increasing and strengthening its presence in the region and increasing the ability of its allies and partners in the region. However, the analysis of Ikenberry ${ }^{38}$ shows that this strategy of containment failed and that even the unquestionable US military supremacy is not effective as an influence in Asia; the economic dimension is more influential than the military power. Beijing has launched several successful economic initiatives, as mentioned above, and the AIIB already has 70-member countries and heads the negotiations at the regional Comprehensive Economic Partnership (RCEP), some trade alliances in the region that aims to gather the ten ASEAN member countries, including China, Australia, New Zealand, India, Japan, and South Korea. It is notable that this group represents almost half of the world's population, slightly below the level of the world GDP. ${ }^{39}$ Even if the agree- 
ment is not reached, the RCEP is the new 'game' in which the US is not present. China's initiatives are important given its regional impact and the fact that it induces the perception of inevitability in relation to the economic future of the sub region under Chinese leadership. A recent study by lkenberry ${ }^{40}$ has shown that the South Asian countries are aware that the US is losing ground and that the Trump administration is not interested in the region and is unlikely to sign a free trade agreement.

\section{Trade war, US protectionism or containment strategy?}

The United States created another way of containment strategy, namely economic containment, which is both dangerous and risky. This is so because such a strategy can affect or, is already affecting other countries around the globe including the US itself. Economic trade wars are imposed with an aim of reducing the amount of imports from a rival country. Economic trade wars have very adverse effects on the rival countries and on the world as a whole. For instance, the prices of commodities increase thus reducing the rate of purchase of the commodities and in return affecting international trade. Also, economic trade wars affect the developmental plans of a region due to a lack of sufficient or standard goods and services that would be only available from the rival countries.

The South China Sea is a very productive region due to the presence of reserves of oil. Oil is a natural component that, as a source of energy, possesses a high monetary value. Also, the region is popular due to the presence of natural gases that are also valuable. The area also harbors a diverse ecosystem and biodiversity due to the available natural resources. In addition, the region is best known for the fishing activities that are carried out here due to the presence of different fish species. Finally, highly valued shipments are passed through the waterway, thus behaving as an efficient path to enhancing trade between countries. However, the economic trade war between America and China is affecting the smooth continuity of activities in the region. For instance, the economic trade wars are affecting the ports of the region (major shipping companies use the waterway to transport their commodities).

Economic trade wars seek to restrict the amount of imports and exports of materials being transported through the water way. Thus, the activities taking place in the ports will be highly affected as they will be 
reduced or cease in extreme cases. Consequently, South China Sea has faced a reduction in the amount of fish in its waters because of overfishing for trading activities.

The looming economic trade wars between the United States and

CEJISS China will reduce the trading activities between the two countries and 3/20I9 to a greater extent to other parts of the world. In that case, it will indirectly affect the demand for fish globally hence providing a solution to the decreasing number of fish in the waters of the region due to overfishing. As a result, the fishing activities will reduce hence allowing more fish that will be available for fishing and sale by the local East Asian fisheries. ${ }^{41}$ These economic trade wars will affect the mining activities of the natural resources due to reduced import and export of the resources in countries due to increased prices. Therefore, the trading activities will decrease as the activity of mining drops as a result of the trade war. The reduction in the mining activity will directly impact the stability of the region as the conflicts and hostility that accompany it should see a decline. ${ }^{42}$ In addition, the availability of military personnel around the waters will decrease as the demand for the resources available in the region decreases due to increased prices that are as a result of the economic trade wars between the two main stakeholders of the South China Sea. ${ }^{43}$

South China Sea is well known to the world, however some of these countries are closely affiliated to the region while others are stakeholders who do not claim the region but harbor interests of the region. One of the international countries that have an interest in the region is the United States. America is keen on taking over the operations of the region thus becoming a domineering force. America provides the region with economic benefits in addition to providing military personnel to the region. South China Sea is also internationally known to Russia. Russia is among the largest provider of arms in the world, therefore it plays an important role in protecting the South China Sea by providing security and in return ensuring its stability. ${ }^{44}$ Australia is an international nation that has the knowledge of the region. Australia plays a role of ensuring the restoration of peace in the region through proactive methods. Australia uses a strategy that involves rules to control the pressure build up in the region. Lastly, Japan is among the international countries that know the South China Sea. Japan pays a very crucial role as it provides trading platforms in the region. Also, Japan is keen on providing security materials for the region due to the crisis 
and conflicts associated to its contestation. It is important to note that the international communities that have knowledge of the region have developed interests in being part of its operation or taking full control of the region courtesy of the economic value and political advantages it harbors. ${ }^{45}$

I came to this conclusion because the economic trade war imposed by the United States is just a vehicle of a containment strategy. The protectionist policy implemented by US is, in my opinion, a 'Machiavellian' way of containing Chinese growth utilizing all means to ensure that China fails to accomplish several goals, such as overtaking the US as the largest economy in the world.

I recognize that my point of view needs deep research on this issue, even upon the full extent of the repercussions of imposing such tariffs to Canada, EU or Japan. Hiroshige Seko, the Japanese Minister of the Economy noted 'If the Japanese auto industry is weakened, it will not be able to invest in the U.S. This works as absolutely no plus for the world economy, and Japanese companies are shipping parts to China to finish them as products there that are exported to the U.S., and the effects are already being felt, Ultimately, it will hurt the U.S. and Chinese economies. ${ }^{46}$

Furthermore, the tariffs imposed on the EU have the same effect. The ultimate target of the trade war campaign is definitely China, Sherman Katz noted, 'whatever damage the conflict could do to U.S. jobs, industry, and consumers, this conflict will jeopardize essential allied collaboration to confront Chinese state capitalism, the underlying cause of much of the current trade conflict:. ${ }^{47}$

Finally, the tariffs that target Canada and the way the US handles this issue is quite curious because all products that have individual components made in China also will be a target. In a recent article published by Mike Blanchfield explaining that the tariffs will start at the frontier, he noted that 'At the Canada-U.S. border, where American customs agents have the broad power to declare anything a Chinese product - even if it was made in Canada'. In other words, 'American customs officials have the discretion to declare any finished product to be of Chinese origin, even if only some of its parts are from China'. ${ }^{48}$ In addition, and in the same article Mike published, Cyndee Todgham Cherniak, a Toronto trade lawyer who has served as an adviser to the Tax Court of Canada, noted that 'Even a Canadian-made make-up brush, a Canadian-made power cord - any of these items would be subject to Io percent duty go- 
ing into the United States. The whole goal is buying American and hire American... So it doesn't bother the U.S. customs agent that Canadian manufacturers will be collateral damage in the U.S.-China fight'. ${ }^{49}$

I called the above a 'Machiavellian' policy because the US adminis-

CEJISS tration does not restrain themselves from hurting partners, allies and 3/20I9 themselves in order to achieve their objectives. It is clear to me that the so-called trade war has one purpose only - containment strategy from the US to stop or delay China's growth. It is in this sense that $\mathrm{I}$ asked, if this three-dimensional strategy of containment followed by US will be enough to contain the bilateral relations between the states mentioned above and China? In my opinion, it is not, and attempting to contain China is useless. As far as I am concerned, China is already a world and regional power. The US response follows the military dynamics, increasing and strengthening its presence in the region and increasing the capacity of its allies and partners in the region. However, my analysis shows that this strategy of containment will fail and that even the unquestionable US military supremacy is not effective as an influence in Asia; the economic dimension is more influential than the military power.

Beijing has launched several successful economic initiatives, as mentioned above, and the AIIB already has 70-member countries and heads the negotiations at the regional Comprehensive Economic Partnership (RCEP), a regional trade agreement that aims to gather the ten ASEAN member countries: Australia, China, India, Japan, New Zealand and South Korea. ${ }^{50}$ It is notable that this group represents almost half of the global inhabitants and capable of representing significant portions of the world's GDP. Even if the agreement is not reached, the RCEP is the new 'game' in which the US is not present. China's initiatives are important given its regional impact and the fact that it induces the perception of inevitability in relation to the economic future of the sub region under Chinese leadership. A recent study has shown that the South Asian countries are aware that the US is losing ground and that the Trump administration is not interested in the region and is unlikely to sign a free trade agreement.

Furthermore, Sherman Katz observed that in 2017 the European Union, Japan, and the USA declared that they will work together to combat market subsidies with China as a target, and the European Commissioner noted: 'There are some grave concerns on China, [which is] massively subsidizing state-owned companies.5. Addition- 
al meetings are scheduled but after the trade war imposed by the US against Japan and the EU, no positive outcome resulted and it is difficult to imagine it will come soon. Tellingly, in July of 20I8, the European Union signed a comprehensive and progressive free trade agreement with Japan.

\section{Geo-economic policy}

Geo-economics is defined by Allison thusly: 'The use of economic instruments (from trade and investment policy to sanctions, cyber-attacks, and foreign aid) to achieve geopolitical goals. ${ }^{52}$ Robert Blackwill and Jennifer Harris in their book War by Other Means: Geo-economics and Statecraft offer another explanation: 'It's not using economic tools for economic purposes, although those are fine, notable objectives. It's using these economic tools to advance a government, a nation's geopolitical interests. ${ }^{53}$ There is nothing novel in this strategy - countries of the past and present have employed and continue to employ geo-economic strategies to achieve their goals. Russia frequently uses its energy resources as leverage over other nations, and an economic sanction is a tool frequently employed by the USA in pursuing its geopolitical interests. Both these nations and others use stateowned or iconic companies to achieve geopolitical ends. The increased focus towards Geo-economics in political dialogue today has occurred due to China's ongoing and successful use of this stratagem.

According to Robert Blackwill, ${ }^{54}$ to counter the possibility of China's successful use of geo-economic stratagem, the US is using the Trans-Pacific Partnership (TPP) as outlined by the Obama administration and withdrawn by the Trump administration in the first phase, although there is current consideration of whether the agreement should be amended. Trump has stated, 'I would do TPP if we were able to make a substantially better deal. If we did a substantially better deal, I would be open to TPP'.55 Shiro Armstrong contended that the benefits of the TPP are poor, indicating that the nature of this agreement is more political than economic. The TPP can be characterized as a preferable excluding agreement, a regional arrangement in which a large world power, such as the United States, should contribute more to the development of investments and global trade rather than blocking the initiatives in progress of other regional powers, such as the ASEAN. It is argued that 'perhaps the biggest issue is that the TPP is in many respects fundamentally a political and a security tool: ${ }^{56}$
The US Strategy for China Containment 
TPP is the American economic backbone in its 'pivot to Asia strategy' and it is important to note how China was left out of the negotiation process. ${ }^{57}$ Leaving China out of trade deals in Asia only jeopardizes any chance of solving the SCS dispute. China is a major player in the conCEJISS flict, the US formation of alliances with other disputants except China $3 / 2019$ is a miscalculation. It only highlights USA's possibly wrong approach to the regional matters. The US has in many occasions insisted that their approach to TPP is not a deal targeting Chinese containment, but to set new global standards as President Obama stated on October $15^{\text {th }}$, 20I5: 'We can't let countries like China write the rules of the global economy. We should write those rules'. Among other purposes, the TPP serves as a tool to curb China's growing economic dominance in Asia. As Walt pointed out, 'although, of course, the TPP will not erase China's asymmetrical economic advantages with respect to the nations of Asia, it will be a vivid demonstration that the United States is determined to compete on the Asian economic playing field'. The TPP may act as either a lucrative opportunity for China or her challenge. The chance for the inclusion of China is still open as noted by Japan's Prime Minister Shinzo Abe when he said, 'it would have significant strategic meaning if China joined the system in the future. ${ }^{58}$ With the current stated conditions for membership, China may, however, be unable to join unless it undertakes significant reforms in the near future. Additionally, there are other challenges for China joining TPP such as the FTA negotiated in Asia. China on its part has established its political standing for 'Greater China' by signing FTA with Taiwan, Macau, and Hong Kong.

During President Obama's administration, the US became closer to Vietnam as a key piece in the US-designed containment policy, in which Vietnam plays a three-dimensional role. As far as the economic dimension is concerned, Vietnam is a member of the Trans-Pacific Partnership (more precisely, a free trade agreement), which intentionally excludes China. In view of the diplomatic dimension of containment, Vietnam supports the Philippines against China in the dispute over the South China Sea and emphasizes cooperation among the member countries of the ASEAN as a legitimate regional forum. ${ }^{59}$ Lastly, as far as the military containment dimension is concerned, the US raised the arms embargo and simultaneously increased financial support for the maritime development of Hanoi, which shows the importance of Vietnam for the US containment strategy. The Philippines 
is not a member country of the TPP, Japan is not present in the ASEAN, and Vietnam has evolved from an enemy to a US strategic partner, which makes Vietnam an imperative piece of the US strategy ${ }^{60}$ However, Vietnam has solid relations with China, so it acts independently. This occurs because Vietnam does not want to be under the influence of any of the powers. Vietnam prefers combining relations with the US and with China to opting for a direct commitment to any of the superpowers. Vietnam emphasizes cooperation with several states simultaneously, such as Russia, Japan, and India. This multi-cooperation enables Vietnam to take its own independent position in a new world that is no longer unipolar.

As Shiro Armstrong, ${ }^{61}$ notes, the US policies have already created a rift in the region. This is true as a parallel - China's FTA with Australia and Pakistan has been finalized and signed while the one with ASEAN member countries is still in progress in order to propel China's relations and regional links with its neighbors. ${ }^{62}$ More recently, ambitious trading negotiations have been launched with South Korea, India and Japan. The Regional Comprehensive Economic Partnership (RCEP) is also a major component of China's web of Asian FTA. The negotiations began in 2013 and brought together some ASEAN members, including Japan, India, New Zealand, China, Australia and South Korea. However, the conclusion of this TPP may push non-members to form to strike a deal that would balance economic impacts of the latter TPP. ${ }^{63}$ Also, as a major geopolitical component, the RCEP would allow China broaden its ties through major trade deals that do not include the US.

According to Kupchan, ${ }^{64}$ the United States, and not China, may be the catalyst for any potential conflict. The West may actually concern themselves too much with the internal nature of the Chinese regime and seek to limit China's power abroad because simply they care less about their domestic policies. In other words, the strong belief in 'American exceptionalism' has deterred the country from accepting the new power as the new 'exceptionalism'. Digressing from whether China's interests are valid or not; China's pursuit of its own geopolitical interests are certainly no more provocative than those of any other major power, including the United States. ${ }^{65}$ China merely seeks to establish its own 'Monroe doctrine' with regards to securing its own interests in the geopolitical corner of the world it occupies. As Kupchan ${ }^{66}$ observed, 'Just as the United States unfurled the Monroe Doctrine to ward off European powers that challenged US hegemony in the West- 
ern Hemisphere, China is set to lay claim to a sphere of influence in Northeast Asia and guardianship of the region's vital sea lanes'. How China's rising confidence may affect American regional interests in the Southeast Asia region depends on how US interests in the region CEIISS are defined. The traditionally considered key Southeast Asia region 3/20I9 interests of the US are: promotion of balance and stability of power, with the main objective of keeping Southeast Asia from being solely dominated by any hegemony; prevention of itself from being edged out of the region by another power or group of powers; protection of sea lanes and freedom of navigation; trade and investment interests; supporting treaty friends and allies; democracy promotion; rule of law; religious freedom; and human rights. A recent addition to this list is the prevention of the region from becoming a base for support of terrorists. The same cliché the U.S always has is they never say their real purpose aloud. America's intention is to suppress the Chinese rise and to prevent a transition of power in the future ${ }^{67}$ Scholars such as Mearsheimer ${ }^{68}$ shared my opinion: "The United States has a critical interest in providing reassurance to its allies and partners in the region that it will maintain a strong security presence to prevent a power vacuum from developing as China rises'.

United States strategy is to prevent the rise of China; Mearsheimer in Peter' interview supported this with 'the United States will, therefore, form a balancing coalition in Asia, which will include most of China's neighbors and the United States. And they will work overtime to try to contain China and prevent it from dominating Asia. ${ }^{69}$

The United States' own interests in the region are diverse. To begin with, the U.S. Navy has long dominated this maritime region, which is a crucial pass for the U.S. warships cruising from the Pacific to the Middle East. The treaty between the United States and Japan also obligates the US to defend Japan and its maritime lifelines. ${ }^{70}$ Therefore, freedom of navigation in the East and South China Sea is a declared U.S. national security priority. China has not yet made the implications of its rise felt on the international scene, and it is as yet unknown what China's true intentions are regarding the established international order - who is to say whether or not China is a revisionist country and a truly dangerous aggressor? One does not observe China declaring itself a 'balancer' to the actions of Russia, the US, or any other great power. Actually, according to Schweller, ${ }^{71}$ America's pivot is to contain China - however, this may even be a case of 'overbalancing', with the 
US reading too much into the actions of China and overestimating the value of these actions upon the world order, thereby seeking to impose itself, thus triggering an arms spiral with China. Schweller, ${ }^{72}$ in his brilliant work, Unanswered Threats continues: 'Overbalancing (or inappropriate balancing), which unnecessarily triggers some costly and dangerous arms spiral because the target is misperceived as an aggressor but is, instead, a defensively minded state seeking only enhance its security'. History has numerous examples of such which can lead to disputes that could potentially turn into conflicts.

The policy of engagement and containment by the US government towards China has in the tail end of President Obama's administration elicited different views after the Secretary of Defense visited India and signed bilateral agreements on military logistics in Mid-April. President Obama later visited Vietnam and announced a lifting of the weapon embargo to Vietnam. ${ }^{73}$ The US senior officials always insist that their bilateral agreements with Vietnam aren't meant to contain China, but such words lack credibility when viewed against the blunt reminders to China on its security obligations to the Philippines as per their bilateral defense treaty.

The containment policy by the US to China has accelerated recently as a result of China's ascending influence in the region and globally. Much emphasis is put on the view of China (by the US) as a competitor, if not a full-blown rival. China and the US are trading partners, with China importing goods worth $\$ 116$ billion from the US while exporting goods worth $\$ 482$ billion to the US in 2015 and their bilateral economic relationship is crucial and extensive. ${ }^{74}$ Despite inflammatory remarks in the recent past towards China by President Donald Trump and other critics, disruption of this economic interdependence between these two countries would be mutually costly.

A repeat of the containment strategy employed towards USSR in the Cold War era is unlikely to work if used in China. During the Cold War era, the economic interdependence between the US and USSR was negligible as opposed to that today between China and the US.

It will also be difficult for the US to successfully assemble dependable alliance(s) against China. Implementing a containment policy against the USSR was quite possible during the Cold War because neither the US nor its allies had much to lose. ${ }^{75}$ The political and economic costs of containing Moscow were therefore minimal. This, however, is a bit tricky with China. Most of US allies in the Far East such as South
The US Strategy

for China

Containment 
Korea and Japan have massive economic dependence with China. Japan's leading trade partner is China. It would not be easy for Japan to lose a major trading partner is support of a confrontational US policy. ${ }^{76}$ Even though Japan has concerns about China's approach in the South

CEJISS Sea China, it would still be non-committing to participate in a hostile 3/2019 containment strategy.

The containment policy against the USSR during the Cold War proved difficult for US leaders as time passed. That was true especially in I970 when Germany's Ostipolitik policy sought better relations with Moscow, East Germany and the rest of the Soviet bloc. The deepened connections grew USSR and democratic Europe; support for the hardline US strategies began to fade. The fading US support was evident in I980's when the US attempted to persuade European allies to decline a proposal for the establishment of a pipeline from the USSR to Western Europe, fearing that the project would give Moscow an unwarranted degree of policy influence. Key European allies rejected that request much to the disappointment of the US.

According to Blackwill and Tellis ${ }^{77}$ America continues to assemble support for a containment policy against China, but it faces minimal chances of success. Few countries that are more reliant on US support may welcome the idea, but large powers may not make firm commitments that may antagonize their ties with China. The containment policy against China is, therefore, a poor option for the US. It will be difficult to solve the SCS and other regional issues without the substantial input from China. ${ }^{78}$ It's nearly impossible to picture an end to the territorial disputes in SCS without cooperation from China, for example.

A consideration of Chinese worldwide view is important in dealing with China's issue of growth. The Chinese are very acute in their history and are quite aware that for many centuries, they see themselves as victims of imperialist domination. As a result, the Chinese leadership do not trust the Western states and are convinced that the Western states are out to contain its ambitions to gain a status in the world.

With that said, a liberal approach to China and the South China Sea disputes would be the most productive approach. The US, by deepening its Chinese ties and taking a less than aggressive approach towards China, plays to Chinese sensitivities and mitigates potential misunderstanding that can cause conflicts. If China feels that they receive the respect they deserve and are included in regional security arrangements, they would probably be more supportive of the US strategic policies. 
Political institutions would surely be liberalized by continued economic growth. Chinese would easily support liberalization of world institutions as they seek to gain influence in international matters.

On the contrary, the realist's approach would antagonize China and lead Beijing to believe that the West is out to suppress its growth. China does not possess sufficient military power to directly confront the US, but American policymakers view Chinese military development as threatening. However, the US treating China as an enemy would lead China to respond in kind. Beijing would build a military to challenge the US presence in Asia while seeking ties with other countries that feel dissatisfied with the US hegemony.

China is strategically working to gain power across the world and gaining control of the SCS is fundamental in gaining national dignity. However, China does not seek to alter the international system of relations and can be useful as a member of the world's security community. The liberal policy can easily help achieve such an objective. When the time comes when China finally shakes the world, it will do so along with the West rather than against.

\section{Conclusion}

In conclusion, the wider concept of the South China Sea dispute and United States containment policy on China can be summarized by different facts. To start with, United States involvement in the South China Sea dispute is a problem rather than a solution or benefit. This is because countries in the region have to choose between two superpowers in the region. Some countries will form allies with United States and others will create allies with China, and this will end up splitting the region into different powers. This means that China should be allowed to dominate the region and bring together countries in the region. This would guarantee peace in the region and eliminate political conflicts due to the South China Sea divided interest.

However, international organizations should be on the lookout to prevent the spread of communism in the region which would put the world at risk of another world war. On the other hand, United States containment policy on China is doomed to fail. This is because China currently is strong both economically and defensively and thus United States need strong allies in Asia. After a critical evaluation of all possible United States allies in the region, strong allies are not ready to partner with the United States because they have their problems to settle and 
they do not want to jeopardize their relationship with China, mainly because of trade partnership. Countries that are likely to form allies with United States are weak and thus they can be of no help to United States.

Provincial inquiry used to be the most legitimate hazard to securi-

CEJISS ty. Similarly, a multilateral level-headed discussion has ended up being 3/20I9 more unsafe and complex in the SCS. Today, most local level-headed discussion is latent and thus a less unique wellspring of contention. In the context of the increasing importance of the ocean resources and the globalization of the world economy, regional countries tend to allot more importance to maritime inquiry. China sees the SCS as lost spaces that should be part of China again, like other lost districts, such as the Diaoyu/Senkaku Islands in the East China Sea. In any case, by taking a more discernible power position in this district, China exposes issues related to its complex nature of vitality.

China presents itself as a major power set on building a friendly world during its peaceful climb. Thus, the need for cooperative neighboring countries is perceived while addressing claims in the SCS. This indicates Chinese determination; however, there is no sign that China is putting it all on the line by surrendering its private money related to improvements through a coercive methodology in the SCS conflict. I suggest that China will expect a central part, paying little regard to the possibility of war or investment in the SCS. With the increase of its ocean fiscal interests, such as resources, sea power and legal limits, China is depended upon to become more unequivocal in the coming years. ${ }^{79}$ Meanwhile, the CCP experts observe that more imperative political interests should be considered. Along these lines, the appearance and improvement of Chinese insistence will no doubt be incremental and confined. Chinese earnest exercises do and will certainly continue to produce uneasiness in Southeastern Asian states and require these regional states to make countermeasures, perhaps with unquestionable or unequivocal assistance from external forces, such as the US.

Of course, given the Chinese emphasis on East Asia and the CCP's need for private money related to progression, China could use its muscle in a limited way and maintain a vital separation from any sudden acceleration of its maritime inquiry in the SCS. As noted above, prompt results from the China-ASEAN Free Trade Agreement (CAFTA) with regard to monetary estimation are necessary in addition to another dynamic related to establishing peace and reducing the es- 
calation of conflict between the claimants. ${ }^{80}$ China joins a fragile influence with a hard influence, which implies a sharp influence. This, together with money-related affiliation, conveys another dynamic into the SCS discussion. In the coming years, the Chinese capacity to modify its developing penchant to show a surer position and its political energy toward joint effort will be tested. It will similarly be a test for Southeastern Asian inquirer states to respond to the changing Chinese approach to managing conflict. In light of misunderstood standards concerning the SCS, the DOC may well be the best option for the diverse solicitor states because it establishes the possibility of maintaining existing conditions, which may be the foundation for a future arrangement of standards.

I believe that the inevitable destiny of the SCS question is the maintenance of existing conditions, in which talks are defended calmly and focused on specific issues. One could argue that this condition is adequate for now and that the inquirers may continue to satisfy their people with remarks and clarifications while avoiding equipped conflict in light of the political and fiscal costs involved. This means living with the standard until improved political and financial relations reduce strains and the likelihood of a political power establishing that no country has a perfect claim to the SCS; thus, there must be exchange to identify verifiable principles to make sense of it. The US has played a basic part in empowering security in Southeastern Asia: 'America 's point in Asia should be change, not quality. ${ }^{81}$ This would involve a plan for the ASEAN states to attract a rising China and a different way.

The US, through its containment policy, has made numerous moves to enable China's rivals in the South China Sea conflict to fight with China and now is moving forward to a trade war that is not beneficial for US allies and US itself; the fact is, it has done more harm than good. The US is not using the containment policy to attempt to help these countries; rather, this is a move to attempt to stop the movement of world superiority from the US to China. In fact, the US is rather hypocritical in this matter since it is not doing anything to help other countries. Rather, this is a move to attempt to remain in power since the US feels that China will gain more power by taking control of this area. This is done without considering that China is already a superpower in the world today given its economic power and strength. The US is only adding injury to wounds in the SCS crisis, in the world also and should stop interfering with matters in the region.
The US Strategy for China Containment 
In order to effectively solve South China Sea problem, the United States should be ready to stay neutral in the conflict. This can happen if the United States tables its genuine reasons behind its involvement in the region. United States should also abandon its strategy of con-

CEJISS taining China. Following these terms would allow countries within 3/20I9 the South China Sea to settle their issues effectively. However, to prevent China over dominance in the region, international organizations should intervene where they should introduce international laws as a way of guiding the whole process. China, on the other hand, should be ready to comply with the set agreements for the good of all players involved. The best option would be leaving South China Sea as free waters where trade and access of natural resources should not be restricted. China establishment of artificial islands in the region should be stopped at all cost by international organizations but not the United States. However, if South China Sea conflicts are not handled in the right way, it can lead to a dangerous crash between United States and China. Countries around the region would also suffer from the conflict especially United States allies such as Philippines and Vietnam.

Joseph Nye noted that the heart of the SCS dispute is not oriented toward natural resources but rather toward the growing power of China as a risk to the status quo position of the US as the leader of the present world order. ${ }^{82}$

Victor Teixeira holds a Ph.D. in International Relations. Victor is a researcher in the Lusíada Research Center on International Politics and Security, Lusíada University of Lisbon. His research interests include China-US Relations; International Relations Theory; Hegemony Theory, and Power Transition. He can be reached at victorale@sapo.pt.

\section{Notes}

I Regilme employs analytic eclecticism, a favorite tool employed in the study of international matters to explain the subject matter of SCS to the reader. Analytic eclecticism refers to approaches to research that consciously address and selectively recombine theoretical and substantive elements of scholarship produced in separate research traditions.

2 Marston \& Co. considers the people, place and environments across the globe as a study tool salient to the problem of SCS. People and their 
interest in politics and environmentally rich regions are an explanation to the problems of SCS.

3 Walt \& Co. addresses the critical subject matter that has been the American foreign policy and how it makes the country over the years. They cite the same for being the problem in the context of SCS.

4 Ikenberry tackles the issues metaphorically by branding the U.S. to be a dragon while the rest of the world as a dragon. How the Dragon is harassed by the eagle is relevant to the SCS issue.

5 Glaser, B. S. (2015, April 07). Conflict in the South China Sea. Retrieved September II, 20I8, from https://www.cfr.org/report/conflict-southchina-sea

6 Ibid.

7 Mearsheimer, John J., 2014. "Can China Rise Peacefully, Why China's Rise Will Not Be Peaceful.”. http://mearsheimer.uchicago.edu/pdfs/Aoo34b.pdf

8 Buszynski, Leszek. 20I2. "The South China Sea: Oil, Maritime Claims, and U.S.-China Strategic Rivalry”. The Washington Quarterly. 35 (2): I39-I56.

9 Mearsheimer (20I4).

Io Fravel, M. Taylor. 20II, "China's Strategy in the South China Sea." Contemporary Southeast Asia: A Journal of International and Strategic Affairs 33.3: 292-319.

II Kissinger, Henry, and Nicholas Hormann. On China. New York: Penguin Press, 20II.

I2 Ikenberry, John G., Lim, and Darren J., 20I7. "China's emerging institutional statecraft, the Asian Infrastructure Investment Bank and the prospects for counter-hegemony”. Brookings Institution, https://www.brookings.edu/ wp-content/uploads/2017/o4/chinas-emerging-institutional-statecraft. pdf

I3 Friedberg, Aron L. A contest for supremacy: China, America, and the struggle for mastery in Asia. WW Norton \& Company, 2011.

I4 Ikenberry (2017).

I5 Logan,J.(2013). (Rep.). Cato Institute. Retrieved from http://www.jstor.org/ stable/resrepo487I

I6 Nye, Joseph S. Jr., 2013, "Work With China, Don't Contain It." The New York Times, January 25.

I7 Ibid.

I8 Krishner, Jonathan. 20I2 "The tragedy of offensive realism: Classical realism and the rise of China." European Journal of International Relations I8.I: $53-75$.

I9 Buszynski (2012).

20 Martel, Frances, 20I7, "Xi Jinping Rallies Communists in three-hour speech: 'Time for us to take centre stage'. http://www.breitbart.com/ national-security/20I7/Io/I8/xi-jinping-rallies-communists-speech-timetake-center-stage/

2I Ibid.

22 Tillerson R., 20I7. "Defining Our Relationship with India for the Next Century”. CSIS, https://www.csis.org/events/defining-our-relationshipindia-next-century-address-us-secretary-state-rex-tillerson/?block4

23 Ibid.

24 Ikenberry G. J., 20I6. Between the Eagle and the Dragon: America, China, and Middle State Strategies in East Asia. Political Science Quarterly, I3I: 9-43. doi:Io.Ioo2/polq.I2430 
25 Navarro, Peter, 2016. "Mearsheimer on Strangling China \& the Inevitability of War", Huffpost, 20I6. https://www.huffingtonpost.com/peter-navarroand-greg-autry/mearsheimer-on-strangling_b_94I7476.html.

26 Mearsheimer (2017).

27 Ibid.

CEJISS 28 Ibid.

3/20I9 29 Mearsheimer (2014). Toward China." Council on Foreign Relations Press.

3I Ibid.

32 Walt, Stephen M., 20II. "The Myth of American Exceptionalism." Foreign Policy.

33 Ikenberry (20I6).

34 Fu, Tse-min R., David J., Gill, Hundman E., Adam P. Liff, and John G., Ikenberry 20I5. "Correspondence: Looking for Asia's Security Dilemma." International Security 40 (Issue 2): I8I-204. DOI: Io.II62/ISEC_c_00220.

35 Ikenberry (2016).

36 Chan, and Steve, 2013. "Economics trumps Politics." Chapter. In Enduring Rivalries in the Asia-Pacific, 134-56. Cambridge: Cambridge University Press. doi:Io.IoI7/CBO978I139649667.007.

37 Ikenberry (20I6).

38 Ibid.

39 Ikenberry, John G., Lim, and Darren J., 20I7. "China's emerging institutional statecraft, the Asian Infrastructure Investment Bank and the prospects for counter-hegemony". Brookings Institution, https://www.brookings.edu/ wp-content/uploads/20I7/o4/chinas-emerging-institutional-statecraft.pdf 40 Ibid.

4I Gardner, H. (20I8). World war Trump: The risks of America's new nationalism.

42 Martel, Frances, 20I7, "Xi Jinping Rallies Communists in three-hour speech: 'Time for us to take centre stage'. http://www.breitbart.com/ national-security/20I7/10/18/xi-jinping-rallies-communists-speech-timetake-center-stage/

43 Magoc, Chris J., and C. David Bernstein. 2018. Imperialism and expansionism in American history: a social, political, and cultural encyclopedia and document collection. http://www.credoreference.com/book/abccliownns.

44 Tseng, Hui-Yi Katherine. 2015. "Taiwan in the South China Sea Disputes: Policies and Prospects". Territorial Disputes in the South China Sea: Navigating Rough Waters. I28-I46.

45 Fang, Yang. 2015. "The South China Sea Disputes: whither a Solution?" Territorial Disputes in the South China Sea: Navigating Rough Waters. I64-I88.

46 Kageyama, Yuri, August 2018 The Associated Press, "Japan official says Trump misunderstands trade". https://www.nsnews.com/ap-interviewjapan-official-says-trump-misunderstands-trade-I.23409770

47 Katz, Sherman, July 20I8. "If the U.S. Gets into a Trade War with the EU, It Will Lose an Ally in Pressuring China", Harvard Business Review. https:// hbr.org/2018/o7/if-the-u-s-gets-into-a-trade-war-with-the-eu-it-willlose-an-ally-in-pressuring-china

48 Blanchfield, Mike. July 2or8, "U.S.-China Trade War Could Hurt Canadian Companies, Consumers", Canadian Press. https://www.huffingtonpost. ca/20I8/o7/15/us-china-trade-war tariffs-canada_a_2348259I/ 
49 Ibid.

50 Regilme, Salvador Santino F. Jr. (2018). Beyond Paradigms: Understanding the South China Sea Dispute Using Analytic Eclecticism. In International Studies. (55)3:I-25 https://doi.org/IO.II77/002088I7I8794527

5I Katz (20I8).

52 Allison, Graham., 20I7. Destined for War: Can America and China Escape Thucydides's Trap?.69-70, Houghton Mifflin Harcourt.

53 Blackwill, R. and Harris J. 2017 "War by other means: geoeconomics and statecraft". The Belknap Press of Harvard University Press.

The US Strategy

for China

Containment

54 Blackwill and Harris (20I7).

55 Trump D. 20I8. CNBC, Interview, https://www.cnbc.com/2018/oI/25/ trump-says-he-would-reconsider-trans-pacific-partnership-trade-deal. html.

56 Armstrong, Shiro P., Australia and the Future of the Trans-Pacific Partnership Agreement (December 9, 20II). EABER Working Paper No. 7I. Available at SSRN: https://ssrn.com/abstract=I970I29 or http://dx.doi. org/I0.2139/ssrn.1970129

57 Blackwell and Tellis (2015).

58 Armstrong (20II).

59 Regilme \& Santino (20I8).

60 Armstrong (20II).

6I Armstrong (20II).

62 Regilme \& Santino (20I8).

63 Armstrong (2OII).

64 Kupchan A., Charles, 20I2. No One's World, the West, the Rising Rest, and the Coming Global Turn. Oxford: Oxford University Press.

65 lbid.

66 Ibid.

67 Schweller, Randall L., 2006. Unanswered Threats: Political Constraints on the Balance of Power. Princeton University Press.

68 Mearsheimer (2014).

69 Navarro (2016).

70 Schweller (2006).

7 I Ibid.

72 Ibid.

73 Kagan, Robert, 20I7. Avoiding War: Containment, Competition and Cooperation in US-China Relations, A Bookings Interview. https://www. brookings.edu/research/avoiding-war-containment-competition-andcooperation-in-u-s-china-relations/

74 Ibid.

75 Kagan (20I7).

76 Ibid.

77 Blackwill and Tellis (20I7).

78 Mearsheimer (20I7).

79 Regilme \& Santino (2018).

8o Regilme \& Santino (20I8).

8I Ibid.

82 Nye (20II). 